This paper was withdrawn on June 6, 2012 (J. Am. Chem. Soc. 2012, 134, 9533).

Supporting Information for:

\title{
A Palladium-Oxo Complex. Stabilization of this Proposed Catalytic Intermediate by an Encapsulating Polytungstate Ligand
}

\author{
Travis M. Anderson ${ }^{1}$, Rui Cao ${ }^{1}$, Elena Slonkina ${ }^{2}$, Britt Hedman ${ }^{3}$, Keith O. \\ Hodgson $^{2,3}$, Kenneth I. Hardcastle ${ }^{1}$, Wade A. Neiwert ${ }^{1}$, Shaoxiong Wu ${ }^{1}$, Martin L. \\ Kirk $^{4}$, Sushilla Knottenbelt ${ }^{4}$, Ezra C. Depperman ${ }^{4}$, Bineta Keita ${ }^{5}$, Louis Nadjo ${ }^{5}$, \\ Djamaladdin G. Musaev, Keiji Morokuma ${ }^{1}$ and Craig L. Hill ${ }^{1, *}$
}

${ }^{1}$ Department of Chemistry, Emory University, Atlanta, Georgia $30322{ }^{2}$ Department of Chemistry, Stanford University, Stanford, California $94305{ }^{3}$ Stanford Synchrotron Radiation Laboratory, SLAC, Stanford University, Stanford, California 94309 ${ }^{4}$ Department of Chemistry, The University of New Mexico, Albuquerque, New Mexico 87131, and ${ }^{5}$ Laboratoire de Chimie Physique, UMR 8000, CNRS, Université Paris-Sud, Bâtiment 350, 91405 Orsay Cedex, France. 


\section{Table of Contents:}

1. General Methods and Materials, page S3

2. Synthesis of $\mathrm{K}_{9} \mathrm{Na}_{4}\left[\mathrm{Pd}^{\mathrm{IV}} \mathrm{O}(\mathrm{OH}) \mathrm{WO}\left(\mathrm{OH}_{2}\right)\left(\mathrm{PW}_{9} \mathrm{O}_{34}\right)_{2}\right]$ (2), page $\mathrm{S} 3$

3. Crystallographic Studies, page S4

4. Titration Studies, page S5

5. Electronic Absorption Studies, page S5

6. ${ }^{17} \mathrm{O}$ NMR Studies, page S6

7. X-ray Absorption Studies, page S8

8. Electrochemical Studies, page S9

9. Computational Procedures and Results (including Scheme S1), page S10

10. Table S1 (X-ray refinement data), page S13

11. Figure S1 (Thermal Ellipsoid Plot), page S14

12. Figure S2 (Infrared and UV-vis/NMR titration data), page S15

13. Table S2 ( $\mathrm{M}=\mathrm{O}$ bond distances and "doming"), page $\mathrm{S} 16$

14. Figure S3 (Electronic absorption data), page S17

15. Figure S4 $\left({ }^{17} \mathrm{O}\right.$ NMR data), page S18

16. Table S3 (EXAFS data, fits), page S19

17. Figure S5 (EXAFS and Fourier transforms), page S20

18. Figure S6 (EXAFS, components of fit 4), page S22

19. Figure S7 (Cyclic voltammogram), page S23 


\section{Experimental}

General Methods and Materials: $\mathrm{Na}_{9}\left[\mathrm{PW}_{9} \mathrm{O}_{34}\right] \cdot 7 \mathrm{H}_{2} \mathrm{O}$ was obtained by the published procedure (Inorganic Syntheses 1990, 27, 96-104) and purity was confirmed by infrared spectroscopy and elemental analysis. Elemental analyses of $\mathrm{Cl}, \mathrm{K}, \mathrm{Na}, \mathrm{P}, \mathrm{Pd}$, and W were performed by Kanti Labs (Mississauga, Canada) and Desert Analytics (Tucson, Arizona). Infrared spectra (2\% sample in $\mathrm{KBr}$ ) were recorded on a Nicolet 510 instrument. The electronic absorption spectra were taken on a Hewlett-Packard 8452A UV-vis spectrophotometer. The average magnetic susceptibility was measured on a Johnson-Matthey Model MSB-1 magnetic susceptibility balance as neat powders at 24 ${ }^{\circ} \mathrm{C}$; the balance was calibrated using $\mathrm{Hg}\left[\mathrm{Co}(\mathrm{SCN})_{4}\right]$ as a standard. Pascal's constants were used to obtain the final diamagnetic corrections. Thermogravimetric data were collected on a TGA 1000 instrument.

Synthesis of $\mathrm{K}_{10} \mathrm{Na}_{3}\left[\mathrm{Pd}^{\mathrm{IV}} \mathrm{O}(\mathrm{OH}) \mathrm{WO}\left(\mathrm{OH}_{2}\right)\left(\mathrm{PW}_{9} \mathbf{O}_{34}\right)_{2}\right]$ (2): A $1.0 \mathrm{~g}(4.2 \mathrm{mmol})$ sample of palladium sulfate $\left(\mathrm{PdSO}_{4}\right)$ is suspended in $50 \mathrm{~mL}$ of acetate buffer $(0.25 \mathrm{M}$ $\mathrm{NaOOCCH}_{3}$ and $\left.0.25 \mathrm{M} \mathrm{HOOCCH}_{3}, \mathrm{pH}=4.9\right)$ at room temperature and $7 \mathrm{~g}(2.8 \mathrm{mmol})$ of $\mathrm{A}-\mathrm{Na}_{9} \mathrm{PW}_{9} \mathrm{O}_{34}$ is added in $c a .1 \mathrm{~g}$ portions quickly with vigorous stirring. After 0.5-1 min, $20 \mathrm{~g}$ of $\mathrm{KCl}$ are added to the nearly clear brown solution $(\mathrm{pH}=3)$, and the solution is stirred at $5{ }^{\circ} \mathrm{C}$ for 2 additional min. A light brown solid is then separated by filtration, dried in air for $10 \mathrm{~min}$ and re-dissolved in $c a .50 \mathrm{~mL}$ of water at $55{ }^{\circ} \mathrm{C}$. The solution becomes red-brown in color upon heating. The $\mathrm{pH}$ of the solution is lowered from 7.5 to 6.5 by the drop-wise addition of $6 \mathrm{M} \mathrm{HCl}$. After cooling to room temperature, the solution is filtered using a fine glass-sintered frit. After an additional 24 to $48 \mathrm{~h}$, small brown plates of 2 appear ( $5 \mathrm{~g}, 73 \%$ yield based on W). The crystals are filtered and dried

in air. Analytical data: IR (2\% KBr pellet, $\left.1200-400 \mathrm{~cm}^{-1}\right)$ : $1089(\mathrm{~m}, \mathrm{sh}), 1076(\mathrm{~s})$, 1018 (s), $945(\mathrm{~m}), 921$ (m), $783(\mathrm{~m}), 700(\mathrm{~m}), 594(\mathrm{~m}), 521(\mathrm{~m}), 445(\mathrm{w})$, and $413(\mathrm{w})$. 
${ }^{31} \mathrm{P}$ NMR $\left(5 \mathrm{mM}\right.$ solution in $\left.\mathrm{D}_{2} \mathrm{O}\right):-11.7 \mathrm{ppm}\left(\Delta v_{1 / 2}=7 \mathrm{~Hz}\right)$. Electronic spectral data (400 - $800 \mathrm{~nm}$, in $\mathrm{H}_{2} \mathrm{O}\left(3.6 \mathrm{mM}\right.$ sample, $1 \mathrm{~cm}$ cell path length)) $\left[\lambda, \mathrm{nm}\left(\varepsilon, \mathrm{M}^{-1} \mathrm{~cm}^{-1}\right)\right]$ : $444 \mathrm{~nm}(272)$ and $512 \mathrm{~nm}$ (sh, 131). Magnetic susceptibility: $\mu_{\mathrm{eff}}=0 \mu_{\mathrm{B}} \mathrm{mol}^{-1}$ at $297 \mathrm{~K}$. Anal. Calcd. for $\mathrm{K}_{10} \mathrm{Na}_{3}\left[\mathrm{Pd}^{\mathrm{IV}} \mathrm{O}(\mathrm{OH}) \mathrm{WO}\left(\mathrm{OH}_{2}\right)\left(\mathrm{PW}_{9} \mathrm{O}_{34}\right)_{2}\right] \cdot 16 \mathrm{H}_{2} \mathrm{O}: \mathrm{K}, 7.03 ; \mathrm{Na}, 1.24 ; \mathrm{P}$, 1.11; Pd, 1.91; W, 62.8. Found (Kanti): $\mathrm{Cl},<0.01 ; \mathrm{K}, 6.79 ; \mathrm{Na}, 1.25 ; \mathrm{P}, 1.17$; Pd, 1.92; W, 63.4. Found (Desert Analytics): Cl, <0.01; K, 7.05; Na, 1.24; P, 1.13; Pd, 1.91; W, 61.8. $[\mathrm{MW}=5565 \mathrm{~g} / \mathrm{mol}]$

Crystallographic Studies. Single-crystal X-ray crystallographic analysis of 2 was performed at Emory University at $173 \mathrm{~K}$ on a Bruker D8 SMART APEX CCD

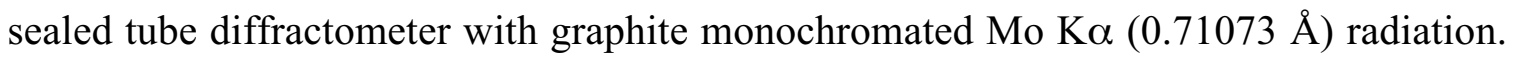
Data collection, indexing, and initial cell refinements were carried out using SMART software (version 5.628). Frame integration and final cell refinements were carried out using SAINT (version 6.36A). An absorption correction was applied using SADABS (version 2.10). The structure was determined using direct methods and difference Fourier techniques. The final R1 scattering factors and anomalous dispersion corrections were taken from the International Tables for X-ray Crystallography. Structure solution, refinement, and generation of publication materials were performed using SHELXTL V6.12 software. Ultra-low-temperature data sets $(30 \mathrm{~K}$ and $90 \mathrm{~K})$ were collected at Texas A \& M University under the direction of J. Reibenspies and the data was processed as described above.

There is disorder in the plane located between the two $\left[\mathrm{A}-\alpha-\mathrm{PW}_{9} \mathrm{O}_{34}\right]^{9-}$ units. This disorder does not affect the positions of any of the atoms in the plane; however, it does cause the positions of the oxo and hydroxo ligands coordinated to Pd to be refined at $50 \%$ occupancy rather than the customary $100 \%$ occupancy. A similar phenomenon was observed by Tourné and Weakley in the closely related complex, $\left[\mathrm{P}_{2} \mathrm{~W}_{21} \mathrm{O}_{71}\left(\mathrm{OH}_{2}\right)_{3}\right]^{6-}$. In their structure, some atoms in the equatorial plane were refined at partial occupancy. 
However, ${ }^{183} \mathrm{~W}$ NMR studies on this complex suggested that no compositional impurities were present. For more information, see J. Chem. Soc., Dalton Trans. 1986, 2237. In the case of $\mathbf{2}$, there were no impurities detected by ${ }^{31} \mathrm{P}$ NMR or elemental analyses, and the disorder was a result of interior steric crowding (from neighboring $\mathrm{K}^{+}$and $\mathrm{O}$ atoms) in the solid state. There are two $\mathrm{K}^{+}$atoms (K1 and K10, see Figure $\mathrm{S} 1$ for the numbering scheme) at the clam-shell opening which have inequivalent geometry. K1 is near the opening of the clam-shell structure while $\mathrm{K} 10$ is inside the opening and weakly interacting with O70 (bound to Pd) and O69 (bound to W19).

Titration Studies: The $\mathrm{pH}$ titrations of $\mathbf{2}$ were performed on $3.6 \mathrm{mM}$ solutions ( $0.2019 \mathrm{~g}$ of 2 dissolved in $10 \mathrm{~mL}$ of de-ionized water), beginning at $\mathrm{pH} 6.5$ (the natural $\mathrm{pH}$ of 2). The $\mathrm{pH}$ was lowered to 2.5 by the dropwise addition of $0.1 \mathrm{M} \mathrm{HCl}$ and then increased again to 6.5 by dropwise addition of $0.1 \mathrm{M} \mathrm{NaOH}$. The results show there is a small inflection point at 3.5, which is expected for the protonation of a $\mathrm{Pd}(\mathrm{IV})-\mathrm{OH}$ unit (Baes, Jr., C. F.; Mesmer, R. E. The Hydrolysis of Cations; John Wiley \& Sons, Inc.: New York, 1976). In addition, UV-vis data show three changes in the d-d band at 444 $\mathrm{nm}$ upon lowering the $\mathrm{pH}$ of the solution below 3.5 (a red shift of $8 \mathrm{~nm}$, loss of a shoulder at $512 \mathrm{~nm}$, and an increase in $\varepsilon$ ). This process is reversible upon increasing the $\mathrm{pH}$ above 3.5 again. The UV-vis experiments are corroborated by similar changes in the ${ }^{31} \mathrm{P} N M R$ spectrum of $\mathbf{2}$ as a function of $\mathrm{pH}$ (see Figure $\mathrm{S} 2$ ).

Electronic Absorption Studies: Electronic absorption spectra of 2 were collected on a Hitachi U-3501 UV-Vis-NIR spectrophotometer using a single-beam configuration at $2.0 \mathrm{~nm}$ resolution. Ultra-low-temperature spectra were collected at $5 \mathrm{~K}$ using a Janis STVP-100 continuous flow cryostat mounted in a custom designed cradle assembly, and the sample temperature was monitored with a Lakeshore silicon-diode (PT-470). The sample was dissolved in a 1:3 water:glycerol mixture in order to obtain a 
high quality optical glass. The resulting solution was injected through a rubber gasket spacer (approximately $1 \mathrm{~mm}$ thick) between two $1 \mathrm{~mm}$ thick Infrasil quartz discs in a custom designed sample holder.

In contrast to the related complex 1 , the ultra-low-temperature $(5 \mathrm{~K})$ electronic spectrum of $\mathbf{2}$ has only two weak absorption bands in the visible region of the spectrum, at $19,750 \mathrm{~cm}^{-1}$ (506 nm; band 1) and $22,700 \mathrm{~cm}^{-1}(441 \mathrm{~nm}$; band 2) (Figure S3). Intense oxygen-to-tungsten charge transfer bands $\left(\mathrm{E}>26,000 \mathrm{~cm}^{-1}\right)$, characteristic of all polytungstates, are found at higher energy. Our analysis of the ultra-low-temperature ligand spectra of $\mathbf{2}$ is based on that for $\mathbf{1}$, with tentative assignments for the $\mathrm{Pd}(\mathrm{IV})$ ligand field bands as e $\rightarrow b_{1}$ (bands 1 and 2) and $b_{2} \rightarrow b_{1}$ (band 2). Spectral fitting indicates that band 2 is likely comprised of two electronic absorption features due to the larger bandwidth. The $\mathrm{e} \rightarrow \mathrm{b}_{1}$ one electron promotion results in two components, one under band 1 and one under band 2, due to the effects of low-symmetry and spin-orbit splitting of the $E$ excited state $\left(A_{1} \rightarrow E\right.$ transition). One-electron promotions to the empty $d_{z 2}$ orbital are viewed as unlikely contributors to the low energy ligand field region due to the inherent large ligand field splitting of $4 \mathrm{~d}$ ions and the very large destabilization of this orbital resulting from strong $\sigma^{*}$ bonding interactions with the terminal oxo donor.

${ }^{17}$ O NMR Studies: ${ }^{17} \mathrm{O}$ NMR spectra were recorded at $81.291 \mathrm{MHz}$ on a Varian UNITY 600 spectrometer. The spectrometer was locked on $\mathrm{CDCl}_{3}$, and all chemical shifts are reported relative to $\mathrm{D}_{2} \mathrm{O}(\delta=0)$. Spectral parameters for ${ }^{17} \mathrm{O}$ were the following: pulse width, $10 \mu \mathrm{s}$; sweep width, $100,000 \mathrm{~Hz}$; $0.01 \mathrm{~s}$ delay; 100,000 transients; 40,000 data points. Spectra were obtained using cylindrical 5-mm o.d. sample tubes ( 7 in). The NMR software package NUTS was used to process the spectra and to correct for "rolling" in the baseline.

A $0.2 \mathrm{~g}(0.036 \mathrm{mmol})$ sample of 2 was dissolved in $2 \mathrm{~mL}$ of distilled water at room temperature and the $\mathrm{pH}$ value of this solution was lowered to 3.0 by the addition of 
$0.5 \mathrm{~mL}$ of $0.1 \mathrm{M} \mathrm{HCl}$. A solution of $0.151 \mathrm{~g}\left[\mathrm{CH}_{3}\left(\mathrm{CH}_{2}\right)_{3}\right]_{4} \mathrm{NBr}$ (tetra- $n$-butylammonium bromide, $0.468 \mathrm{mmol}$ ) in $20 \mathrm{~mL}$ of $\mathrm{CH}_{2} \mathrm{Cl}_{2}$ was then added quickly with vigorous stirring for 2 min. Upon standing, the mixture separated into a clean red-brown organic layer and a cloudy white aqueous layer. The organic layer was separated and filtered using a 0.45 $\mu \mathrm{m}$ nylon membrane filter, and then was evaporated to near dryness (on a rotavap) at room temperature. The resulting red-brown solid was dissolved in $5 \mathrm{~mL}$ of $\mathrm{CH}_{3} \mathrm{CN}$. The addition of $50 \mathrm{~mL}$ of anhydrous diethyl ether to this solution caused an immediate precipitate that was then collected with a fine glass-sintered filter. Re-dissolution of the red-brown solid in $\mathrm{CH}_{3} \mathrm{CN}$ followed by re-precipitation with $\mathrm{Et}_{2} \mathrm{O}$ five times afforded a pure sample of the tetra- $n$-butylammonium salt of 2 . The purity was checked by ${ }^{31} \mathrm{P}$ $\mathrm{NMR}$; one peak is present at $-13.3 \mathrm{ppm}$ in $\mathrm{CH}_{3} \mathrm{CN} / \mathrm{CDCl}_{3}$ solvent. ${ }^{17} \mathrm{O}$-Enriched water (0.1 mL) was added to this $\mathrm{CH}_{3} \mathrm{CN}$ solution, and the solution was allowed to react for 2 days at $50{ }^{\circ} \mathrm{C}$. The solution was again evaporated to near dryness (on a rotavap), and the resulting red-brown solid was dissolved in $0.5 \mathrm{~mL}$ of $\mathrm{CH}_{3} \mathrm{CN} / \mathrm{CDCl}_{3}$.

A sample of $\mathrm{K}_{10} \mathrm{P}_{2} \mathrm{~W}_{20} \mathrm{O}_{70} \cdot 24 \mathrm{H}_{2} \mathrm{O}$ was prepared by the literature procedure (partial translation of Can. J. Chem. 1987, 65, 568-573: A mixture of $100 \mathrm{~mL}$ of $1 \mathrm{M}$ potassium tungstate and $10 \mathrm{~mL}$ of $1 \mathrm{M}$ phosphoric acid was acidified slowly with $51 \mathrm{~mL}$ of $3 \mathrm{M} \mathrm{HCl}$. The white precipitate that appeared immediately was redissolved by bringing the solution to a boil. Then, the solution was left at room temperature and the white crystals that began to appear after one day were filtered off and recrystallized in a minimum of water. $)$. A $0.2 \mathrm{~g}(0.035 \mathrm{mmol})$ sample of $\mathbf{P}_{\mathbf{2}} \mathbf{W}_{\mathbf{2 0}}\left(\mathrm{K}_{10} \mathrm{P}_{2} \mathrm{~W}_{20} \mathrm{O}_{70} \cdot 24 \mathrm{H}_{2} \mathrm{O}\right)$ was dissolved in $0.1 \mathrm{~mL}$ of $10 \%{ }^{17} \mathrm{O}$-enriched water at $50{ }^{\circ} \mathrm{C}$ and aged for 2 days. This solution was then mixed with $2 \mathrm{~mL}$ of water as well as a solution of $0.113 \mathrm{~g}$ $\left[\mathrm{CH}_{3}\left(\mathrm{CH}_{2}\right)_{3}\right]_{4} \mathrm{NBr}$ (tetra- $n$-butylammonium bromide, $0.352 \mathrm{mmol}$ ) in $20 \mathrm{~mL} \mathrm{CH} \mathrm{Cl}_{2}$ with vigorous stirring for $2 \mathrm{~min}$. Upon standing, the mixture separated into a clean colorless organic layer and a cloudy white aqueous layer. The organic layer was separated and filtered using a $0.45-\mu \mathrm{m}$ nylon membrane filter and then was evaporated to near dryness 
(on a rotavap) at room temperature. The resulting white solid was dissolved in $5 \mathrm{~mL}$ of $\mathrm{CH}_{3} \mathrm{CN}$. The addition of $50 \mathrm{~mL}$ of anhydrous diethyl ether to this solution produced an immediate precipitate that was collected with a fine glass-sintered filter. Re-dissolution of the red-brown solid in $\mathrm{CH}_{3} \mathrm{CN}$ followed by re-precipitation with $\mathrm{Et}_{2} \mathrm{O}$ five times afforded a pure sample of the tetra- $n$-butylammonium salt of $\mathbf{P}_{\mathbf{2}} \mathbf{W}_{\mathbf{2 0}}$. The purity was checked by ${ }^{31} \mathrm{P}$ NMR; one peak is present at $-12.4 \mathrm{ppm}$.

X-ray Absorption Studies: A 120-mg crystalline sample of 2 was finely ground, and the resultant powder was pressed into a $1 \mathrm{~mm}$ thick aluminum spacer with X-ray transparent kapton windows. The $\mathrm{Pd} K$-edge X-ray absorption spectra for $\mathbf{2}$ were measured at the Stanford Synchrotron Radiation Laboratory (SSRL) on focused (Rhcoated toroid) 30-pole wiggler beam line 10-2 with the ring operating at $3 \mathrm{GeV}, 85-100$ mA. A liquid nitrogen cooled $\operatorname{Si}(220)$ monochromator was utilized for energy selection at the $\mathrm{Pd} K$-edge. The monochromator was detuned $30 \%$ at $25345 \mathrm{eV}$ to minimize higher harmonic components in the X-ray beam. Data were collected in transmission mode, and internal energy calibration was performed by simultaneous measurement of the absorption of a Pd foil placed between two ionization chambers located after the sample. The first inflection point of the foil was assigned to $24349.0 \mathrm{eV}$. The sample was maintained at $10 \mathrm{~K}$ using an Oxford Instruments CF1208 continuous flow liquid helium cryostat. Three scans of the energy range $24020-25345 \mathrm{eV}$ were collected and averaged. The averaged data were processed by fitting a first-order polynomial to the pre-edge region and subtracting this background from the entire spectrum. A threeregion spline of orders 2,3 , and 3 was used to model the smooth background above the edge.

Theoretical EXAFS signals were calculated using FEFF (version 7.02, Ankudinov, A. L.; Rehr, J. J. Phys. Rev. B 1997, 56, R1712-R1715), and refinements of the structural model to the data were done by a non-linear least-squares fitting process in 
$k$-space using EXAFSPAK. Atom coordinates for the initial model were obtained from the crystallographic structure of $\mathbf{2}$. The experimental energy threshold $E_{0}$ was chosen as $24370 \mathrm{eV}$ and was allowed to vary by a common amount $\left(\Delta E_{0}\right)$ for all components within a given fit. The structural parameters that were varied during the refinements included the bond distance $(R)$ and the bond variance $\left(\sigma^{2}\right)$.

Electrochemical Studies: Measurements were performed using a glassy carbon electrode in a $\mathrm{pH} 4.5$ buffer. The results indicate that $\mathbf{2}$, its $\mathrm{Pd}(\mathrm{II})$-precursor (i.e. $\left.\left[\mathrm{Pd}^{\mathrm{II}}\left(\mathrm{WO}\left(\mathrm{OH}_{2}\right)\right)\left(\mathrm{PW}_{9} \mathrm{O}_{34}\right)_{2}\right]^{12-}\right)$, and $\mathrm{Pd}(\mathrm{II})$ (from $\left.\mathrm{PdSO}_{4}\right)$ have distinct electrochemical behaviors. Due to the limited stability of $\left[\mathrm{Pd}^{\mathrm{II}}\left(\mathrm{WO}\left(\mathrm{OH}_{2}\right)\right)\left(\mathrm{PW}_{9} \mathrm{O}_{34}\right)_{2}\right]^{12-}$, further comparisons are restricted to $\mathbf{2}$, a few $\mathrm{Pd}(\mathrm{II})$-substituted polytungstates recently reported in the literature,[1-3] and uncomplexed $\mathrm{Pd}(\mathrm{II})$. A reduction peak potential for 2 is observed at $\mathrm{E}_{\mathrm{pc}}=-0.47 \mathrm{~V}$ (vs $\mathrm{SCE}$ ), a value substantially more negative than uncomplexed $\mathrm{Pd}(\mathrm{II})\left(\mathrm{E}_{\mathrm{pc}}=-0.28 \mathrm{~V}\right.$ vs $\left.\mathrm{SCE}\right)$. At equal concentrations, 2 has both a smaller diffusion coefficient and a larger current intensity than $\mathrm{Pd}(\mathrm{II})$ alone. The larger current intensity of $\mathbf{2}$ is attributed to the larger number of electrons involved in its reduction compared to $\mathrm{Pd}(\mathrm{II})$, while the negative potential shift for the reduction of $\mathbf{2}$ is rationalized by the fact that the terminal oxo ligand is a strong $\pi$ electron donor (despite the high electronegativity of oxygen). The reduction wave of $\mathbf{2}$ is observed at a more negative potential than the corresponding process found in the $\mathrm{Pd}(\mathrm{II})$-substituted polytungstate, $\left[\mathrm{Cs}_{2} \mathrm{~K}\left(\mathrm{H}_{2} \mathrm{O}\right)_{7} \mathrm{Pd}_{2} \mathrm{WO}\left(\mathrm{H}_{2} \mathrm{O}\right)\left(A-\alpha-\mathrm{SiW}_{9} \mathrm{O}_{34}\right)_{2}\right]^{9-}(3)\left(\mathrm{E}_{\mathrm{pc}}=-0.32 \mathrm{~V}\right.$ vs SCE).[2] Both 2 and 3 have the same current intensity for the Pd-reduction waves. Finally, the numbers of electrons involved in the exhaustive reductions of the Pd centers within 2 (at $-0.45 \mathrm{~V}$ vs SCE), 3 (at $-0.33 \mathrm{~V}$ vs SCE), and $\mathrm{Pd}(\mathrm{II})$ alone (at $-0.32 \mathrm{~V}$ vs SCE) were determined by controlled potential coulometry and found to be 4,4 and 2 electrons per molecule (or per cation), respectively. 
Regardless of the compound, the observed first reduction wave features the reductive deposition of $\mathrm{Pd}=\mathrm{O}$ or $\mathrm{Pd}(\mathrm{II})$ into $\mathrm{Pd}^{0}$. This was previously observed with other Pd(II)-substituted POMs.[1-3] Figure S7 reveals the main characteristics of a relatively thick film built up from 2. The scan rate was $2 \mathrm{mV} \mathrm{s}^{-1}$. The deposition of $\mathrm{Pd}^{0}$ on the electrode surface in the negative potential domain is immediately followed by a sharp cathodic peak (with a sharp and narrow anodic counterpart) that both feature hydrogen sorption/desorption processes. The domain starting from $0.0 \mathrm{~V}$ to $+1.0 \mathrm{~V}$ (vs SCE) in the positive potential direction and back to $0.0 \mathrm{~V}$ (vs SCE) unambiguously represents the oxidation of the deposited Pd surface followed by the reduction of the oxide at $+0.148 \mathrm{~V}$ (vs SCE). Even the two step oxidation of the surface at $+0.440 \mathrm{~V}$ (vs SCE) and +0.630 $\mathrm{V}$ (vs SCE) are characteristic of thick $\mathrm{Pd}^{0}$ films.[4] In summary, the cyclic voltammogram featured in Figure S7 has essentially the same characteristics as those observed for the deposition of $\mathrm{Pd}^{0}$ on a glassy carbon electrode surface from $\mathrm{Pd}(\mathrm{II})$ solutions.[1-4 and references therein]

References for electrochemical work:

[1] Bi, L.-H.; Reicke, M.; Kortz, U.; Keita, B.; Nadjo, L.; Clark, R. J. Inorg. Chem. 2004, $43,3915-3920$.

[2] Bi, L.-H.; Kortz, U.; Keita, B.; Nadjo, L.; Borrmann, H. Inorg. Chem. 2004, 43, 83678372.

[3] Bi, L.-H.; Kortz, U.; Keita, B.; Nadjo, L.; Daniels, L. Eur. J. Inorg. Chem. 2005, 3034-3041.

[4] Lubert, K-H.; Guttmann, M.; Beyer, L.; Kalcher, K. Electrochem. Commun. 2001, 3, 102-106.

Computational Procedures and Results: Complete-Active-Space-SelfConsistent-Field CASSCF(20el/14orb)) calculations, inclusive of all valence electrons 
and orbitals, on the $\left[\mathrm{OPd}^{\mathrm{IV}}(\mathrm{OH})\right]^{1-}$ model for $\mathrm{K}_{10} \mathrm{Na}_{3}\left[\mathrm{Pd}^{\mathrm{IV}} \mathrm{O}(\mathrm{OH}) \mathrm{WO}\left(\mathrm{OH}_{2}\right)\left(\mathrm{PW}_{9} \mathrm{O}_{34}\right)_{2}\right]$, 2 , were conducted.[1] These calculations indicate that the ground electronic state of this model is an open-shell singlet state with the following valence-electron configuration $[\sigma(\mathrm{Pd}-\mathrm{OH})]^{2}[\sigma(\mathrm{Pd}=\mathrm{O})]^{2}[\delta(\mathrm{Pd})]^{4}[\pi(\mathrm{OH})]^{2}[\pi(\mathrm{Pd}=\mathrm{O})]^{4}\left[\sigma^{*}(\mathrm{Pd}=\mathrm{O})\right]^{2}\left[\pi^{*}(\mathrm{Pd}=\mathrm{O})\right]^{2}[\sigma(\mathrm{Pd})]^{0}$

(Scheme S1).

$$
\text { mainly } \operatorname{Pd}\left(\mathrm{sd}_{\mathrm{zz}}\right)
$$

$$
\begin{aligned}
& \begin{array}{lllll}
\pi * \text {-antibonding } & \mathrm{Pd}\left(\mathrm{d}_{\mathrm{xz}}\right)-\mathrm{O}\left(\mathrm{p}_{\mathrm{x}}\right) \\
\mathrm{Pd}\left(\mathrm{d}_{\mathrm{yz}}\right)-\mathrm{O}\left(\mathrm{p}_{\mathrm{y}}\right) & \mathbf{A} & \frac{1}{\boldsymbol{\gamma}} & -0.0105 \\
& & -0.0040
\end{array} \\
& \text { O*-antibonding } \quad \mathrm{Pd}\left(\mathrm{sd}_{\mathrm{zz}}\right)-\mathrm{O}\left(\mathrm{p}_{\mathrm{z}}\right) \quad \frac{\mathrm{A}}{\mathrm{V}} \quad-0.1645
\end{aligned}
$$

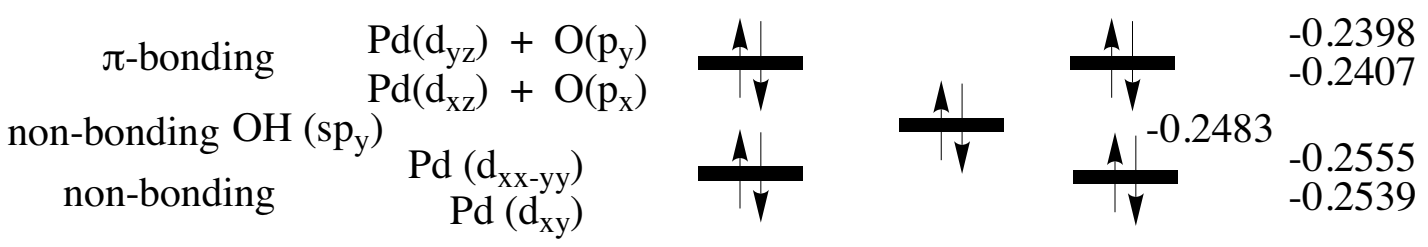

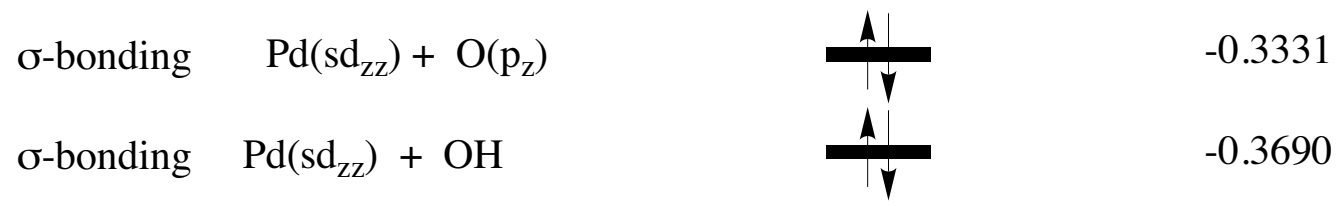

Scheme S1. Molecular orbital diagram of the model $\left[\mathrm{OPd}^{\mathrm{IV}}(\mathrm{OH})\right]^{1-}$. Here we have presented only important orbitals of this model. All energetics are in a.u.

The lowest triplet state with the same orbital occupancy lies only $3.3 \mathrm{kcal} / \mathrm{mol}$ higher in energy. Significantly, the DFT method (e.g. B3LYP) incorrectly describes the lowerlying states of this $\left[\mathrm{OPd}^{\mathrm{IV}}(\mathrm{OH})\right]^{1-}$ model. At the B3LYP level, the triplet state is the ground state, while the lowest singlet state with the following valence-electron configuration, $[\sigma(\mathrm{Pd}-\mathrm{OH})]^{2}[\sigma(\mathrm{Pd}=\mathrm{O})]^{2}[\delta(\mathrm{Pd})]^{4}[\pi(\mathrm{OH})]^{2}[\pi(\mathrm{Pd}=\mathrm{O})]^{4}\left[\sigma^{*}(\mathrm{Pd}=\mathrm{O})\right]^{2}[\sigma(\mathrm{Pd})]^{2}$ $\left[\pi^{*}(\mathrm{Pd}=\mathrm{O})\right]^{0}$, lies about $19.1 \mathrm{kcal} / \mathrm{mol}$ higher in energy.

References for computational work: 
[1] CASSCF calculations were performed by the MOLPRO packages [2] using Stuttgart group [3] ECP and corresponding basis sets for transition metal atoms and standard 6$31 \mathrm{G}^{* *}$ basis sets for main group elements. Density Functional B3LYP calculations have been performed at the same basis sets using the Gaussian_2003 software package.[4]

[2] MOLPRO, version 2002.3: Amos, R. D.; Bernhardsson, A.; Berning, A.; Celani, P.; Cooper, D. L.; Deegan, M. J. O.; Dobbyn, A. J.; Eckert, F.; Hampel, C.; Hetzer, G.; Knowles, P. J.; Korona, T.; Lindh, R.; Lloyd, A.W.; McNicholas, S. J.; Manby, F. R.; Meyer, W.; Mura, M. E.; Nicklass, A.; Palmieri, P.; Pitzer, R.; Rauhut, G.; Schütz, M.; Schumann, U.; Stoll, H.; Stone, A. J.; Tarroni, R.; Thorsteinsson, T.; Werner, H.-J. 2002, University of Birmingham, UK.

[3] (a) Dolg, M.; Wedig, U.; Stoll, H.; Preuss, H. J. Chem. Phys. 1987, 86, 866. (b) Schwerdtfeger, P.; Dolg M.; Schwarz, W.H.; Bowmaker, G.A.; Boyd, P.D.W. J.Chem.Phys. 1989, 91, 1762. (c) Andrae, D.; Haubermann, U.; Dolg, M.; Stoll, H.; Preuss, H. Theor.Chim.Acta 1990, 77, 123. (d) Bergner, A.; Dolg M.; Kychle, W.; Stoll, H.; Preuss, H. Mol.Phys. 1993, 80, 1431.

[4] Gaussian 03, Revision C.02, Frisch, M. J.; Trucks, G. W.; Schlegel, H. B.; Scuseria, G. E.; Robb, M. A.; Cheeseman, J. R.; Montgomery, Jr., J. A.; Vreven, T.; Kudin, K. N.; Burant, J. C.; Millam, J. M.; Iyengar, S. S.; Tomasi, J.; Barone, V.; Mennucci, B.; Cossi, M.; Scalmani, G.; Rega, N.; Petersson, G. A.; Nakatsuji, H.; Hada, M.; Ehara, M.; Toyota, K.; Fukuda, R.; Hasegawa, J.; Ishida, M.; Nakajima, T.; Honda, Y.; Kitao, O.; Nakai, H.; Klene, M.; Li, X.; Knox, J. E.; Hratchian, H. P.; Cross, J. B.; Bakken, V.; Adamo, C.; Jaramillo, J.; Gomperts, R.; Stratmann, R. E.; Yazyev, O.; Austin, A. J.; Cammi, R.; Pomelli, C.; Ochterski, J. W.; Ayala, P. Y.; Morokuma, K.; Voth, G. A.; Salvador, P.; Dannenberg, J. J.; Zakrzewski, V. G.; Dapprich, S.; Daniels, A. D.; Strain, M. C.; Farkas, O.; Malick, D. K.; Rabuck, A. D.; Raghavachari, K.; Foresman, J. B.; Ortiz, J. V.; Cui, Q.; Baboul, A. G.; Clifford, S.; Cioslowski, J.; Stefanov, B. B.; Liu, G.; Liashenko, A.; Piskorz, P.; Komaromi, I.; Martin, R. L.; Fox, D. J.; Keith, T.; Al-Laham, M. A.; Peng, C. Y.; Nanayakkara, A.; Challacombe, M.; Gill, P. M. W.; Johnson, B.; Chen, W.; Wong, M. W.; Gonzalez, C.; and Pople, J. A.; Gaussian, Inc., Wallingford CT, 2003. 
Table S1. Crystal data and structural refinement for the X-ray structures of $\mathrm{K}_{10} \mathrm{Na}_{3}\left[\mathrm{Pd}^{\mathrm{IV}}(\mathrm{O})(\mathrm{OH}) \mathrm{WO}\left(\mathrm{OH}_{2}\right)\left(\mathrm{PW}_{9} \mathrm{O}_{34}\right)_{2}\right] \cdot 16 \mathrm{H}_{2} \mathrm{O}(2)$ at three different temperatures.

\begin{tabular}{|c|c|c|c|}
\hline molecular formula & $\mathrm{H}_{35} \mathrm{~K}_{10} \mathrm{Na}_{3} \mathrm{O}_{89} \mathrm{P}_{2} \mathrm{PdW}_{19}$ & $\mathrm{H}_{34} \mathrm{~K}_{10} \mathrm{Na}_{3} \mathrm{O}_{89} \mathrm{P}_{2} \mathrm{PdW}_{19}$ & $\mathrm{H}_{34} \mathrm{~K}_{10} \mathrm{Na}_{3} \mathrm{O}_{89} \mathrm{P}_{2} \mathrm{PdW}_{19}$ \\
\hline formula wt & 5580.69 & 5580.69 & 5580.69 \\
\hline temperature $(\mathrm{K})$ & $173(2)$ & $90(2)$ & $30(2)$ \\
\hline radiation $(\lambda, \AA)$ & 0.71073 & 0.71073 & 0.71073 \\
\hline crystal system & triclinic & triclinic & triclinic \\
\hline space group & $P-1(\# 2)$ & $P-1(\# 2)$ & $P-1(\# 2)$ \\
\hline unit cell dimensions & & & \\
\hline$a(\AA)$ & $11.8734(15)$ & $11.9500(8)$ & $11.9383(16)$ \\
\hline$b(\AA)$ & $17.225(2)$ & $17.3589(12)$ & $17.332(2)$ \\
\hline$c(\AA)$ & $22.814(3)$ & $22.9619(16)$ & $22.940(3)$ \\
\hline$\alpha\left(^{\circ}\right)$ & $90.536(2)$ & $90.478(1)$ & $90.414(3)$ \\
\hline$\beta\left(^{\circ}\right)$ & $103.247(2)$ & $103.281(1)$ & $103.278(2)$ \\
\hline$\gamma\left(\left(^{\circ}\right)\right.$ & $108.671(2)$ & $108.628(1)$ & $108.585(2)$ \\
\hline Volume $\left(\AA^{3}\right)$ & $4285.3(9)$ & $4375.7(5)$ & $4362.1(10)$ \\
\hline$Z$ & 2 & 2 & 2 \\
\hline$\rho_{\text {calcd }}\left(\mathrm{g} \mathrm{cm}^{-3}\right)$ & 4.324 & 4.230 & 4.244 \\
\hline$\mu\left(\mathrm{mm}^{-1}\right)$ & 26.245 & 25.703 & 25.783 \\
\hline $\mathrm{F}(000)$ & 4902 & 4890 & 4890 \\
\hline crystal size $\left(\mathrm{mm}^{3}\right)$ & $0.20 \times 0.13 \times 0.04$ & & \\
\hline $\begin{array}{l}\theta \text { range for data } \\
\text { collection }\end{array}$ & 2.28 to $28.31^{\circ}$ & 1.86 to $28.26^{\circ}$ & 1.86 to $28.30^{\circ}$ \\
\hline index range & $-15 \leq h \leq 15$ & $-15 \leq h \leq 15$ & $-15 \leq \mathrm{h} \leq 15$ \\
\hline & $-22 \leq \mathrm{k} \leq 22$ & $-22 \leq \mathrm{k} \leq 18$ & $-22 \leq \mathrm{k} \leq 23$ \\
\hline & $-30 \leq 1 \leq 30$ & $-24 \leq 1 \leq 29$ & $-29 \leq 1 \leq 29$ \\
\hline reflections collected & $593 \overline{46}$ & 26326 & 50411 \\
\hline independent & 21214 & 19071 & 20284 \\
\hline reflections & {$[\mathrm{R}(\mathrm{int})=0.0546]$} & {$[\mathrm{R}($ int $)=0.0398]$} & {$[\mathrm{R}(\mathrm{int})=0.0435]$} \\
\hline absorption correction & $\begin{array}{l}\text { semi-empirical } \\
\text { from equivalents }\end{array}$ & $\begin{array}{l}\text { semi-empirical } \\
\text { from equivalents }\end{array}$ & $\begin{array}{l}\text { semi-empirical } \\
\text { from equivalents }\end{array}$ \\
\hline $\max$ and $\min$. & 0.4199 and & 1.00 and & 1.00 and \\
\hline transmission & 0.0772 & 0.1974 & 0.3901 \\
\hline refinement method & $\begin{array}{l}\text { full-matrix least- } \\
\text { squares on } \mathrm{F}^{2}\end{array}$ & $\begin{array}{l}\text { full-matrix least- } \\
\text { squares on } \mathrm{F}^{2}\end{array}$ & $\begin{array}{l}\text { full-matrix least- } \\
\text { squares on } \mathrm{F}^{2}\end{array}$ \\
\hline data/restraints/param. & $21214 / 0 / 703$ & $19071 / 0 / 703$ & $20284 / 0 / 708$ \\
\hline goodness-of-fit on $\mathrm{F}^{2}$ & 1.202 & 1.026 & 1.083 \\
\hline final $\mathrm{R}$ indices & $\mathrm{R} 1^{a}=0.0571$ & $\mathrm{R} 1^{a}=0.0782$ & $\mathrm{R} 1^{a}=0.0580$ \\
\hline$[\mathrm{R}>2 \sigma(\mathrm{I})]$ & $\mathrm{wR} 2^{b}=0.1282$ & $\mathrm{wR} 2^{b}=0.2025$ & $\mathrm{wR} 2^{b}=0.1496$ \\
\hline $\mathrm{R}$ indices (all data) & $\begin{array}{l}\mathrm{R} 1^{a}=0.0615 \\
\mathrm{wR} 2^{b}=0.1303\end{array}$ & $\begin{array}{l}\mathrm{R} 1^{a}=0.0893 \\
\mathrm{wR} 2^{b}=0.2137\end{array}$ & $\begin{array}{l}\mathrm{R} 1^{a}=0.0641 \\
\mathrm{wR} 2^{b}=0.1555\end{array}$ \\
\hline
\end{tabular}

\footnotetext{
${ }^{a} \mathrm{R}_{1}=\Sigma|| F_{\mathrm{o}}|-| F_{\mathrm{c}}|| /\left|F_{\mathrm{o}}\right| \cdot{ }^{b} \mathrm{wR}_{2}=\left\{\Sigma\left[w\left(F_{\mathrm{o}}{ }^{2}-F_{\mathrm{c}}{ }^{2}\right)^{2}\right] / \Sigma\left[w\left(F_{\mathrm{o}}{ }^{2}\right)^{2}\right]\right\}^{0.5}$.
} 
Figure S1. Thermal ellipsoid plot (50\% probability surfaces) and numbering scheme for 2.

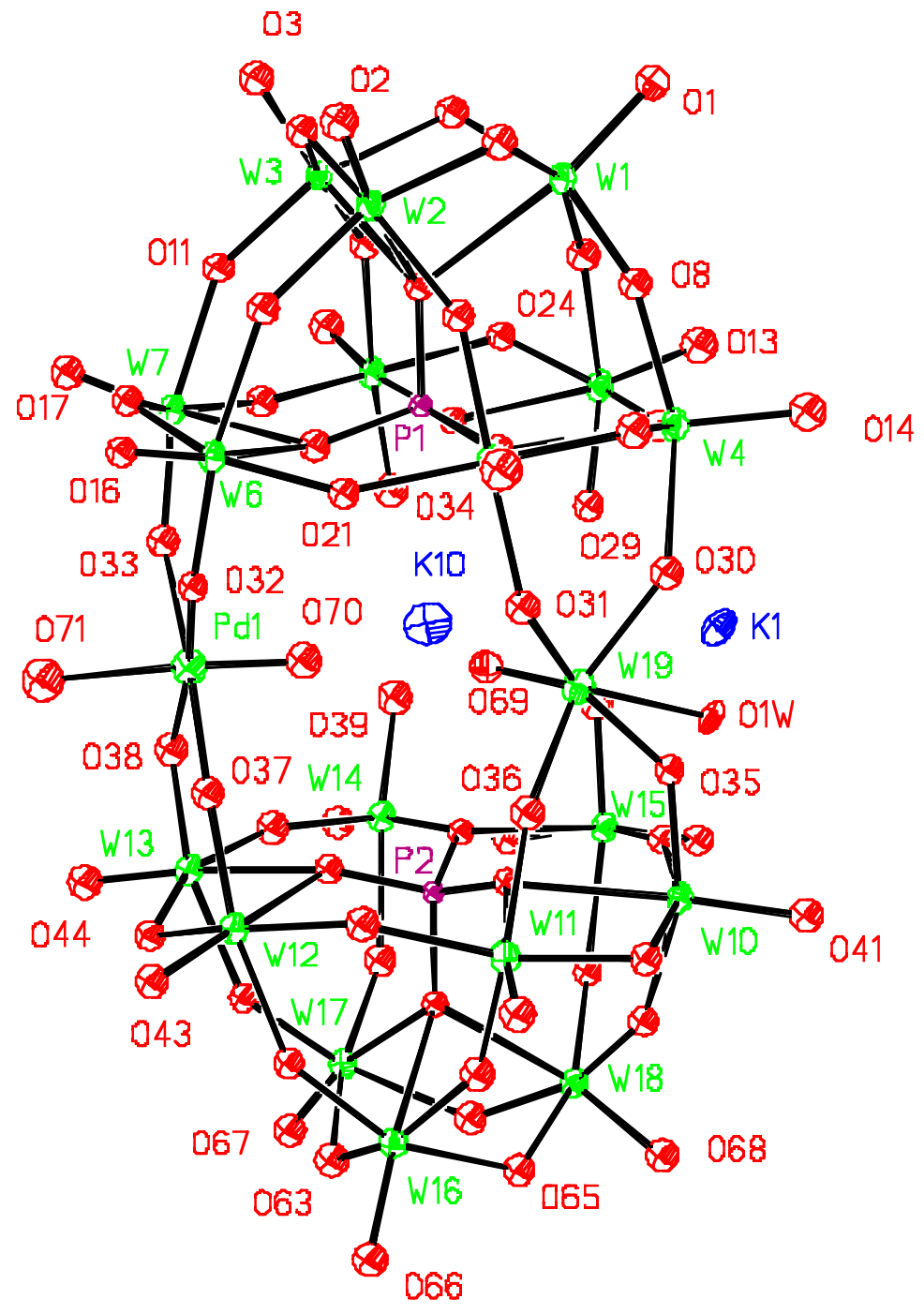


Figure S2. (A) Infrared (B) ${ }^{31} \mathrm{P} N M R$ and (C) UV-vis spectra of 2 (as made, after titration with $\mathrm{HCl}$ and then $\mathrm{NaOH}$ ). The $\mathrm{UV}$-vis experiments are corroborated by similar changes in the ${ }^{31} \mathrm{P}$ NMR spectrum of 2 as a function of $\mathrm{pH}$.

A

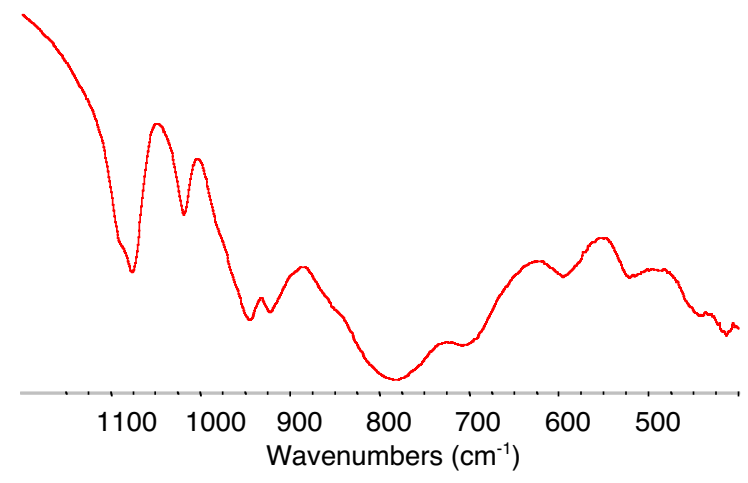

B

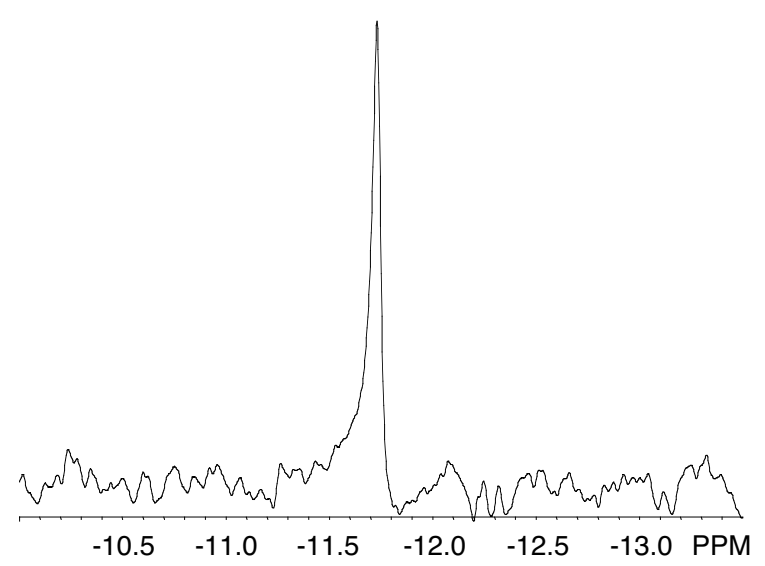

C

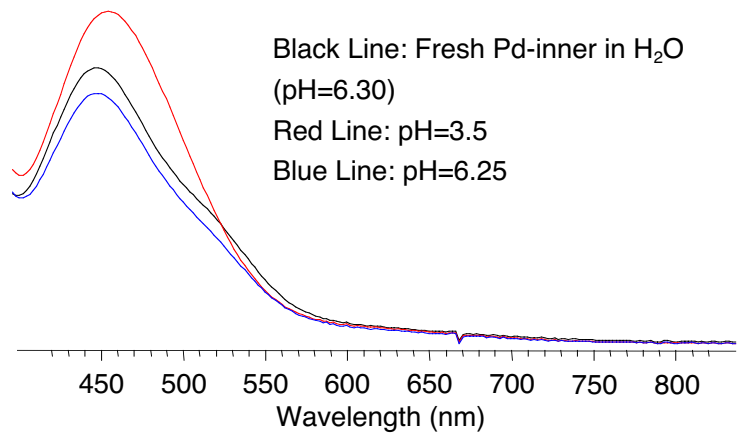


Table S2. Average terminal $\mathrm{M}=\mathrm{O}$ and out-of-plane ("doming") displacements $(\AA)$ as a function of location and temperature within 2 .

\begin{tabular}{|c|c|c|c|c|c|c|c|}
\hline \multirow[t]{2}{*}{ Location } & \multicolumn{4}{|c|}{$\mathbf{M}=\mathbf{O}$} & \multicolumn{3}{|c|}{ Doming Distance (Plane $\cdots \mathbf{M})^{a}$} \\
\hline & & $30 \mathrm{~K}$ & $90 \mathrm{~K}$ & $173 K$ & $30 \mathrm{~K}$ & $90 \mathrm{~K}$ & 173K \\
\hline \multirow[t]{2}{*}{ Equatorial $^{b}$} & $\mathrm{Pd}=\mathrm{O}^{e}$ & $1.60(2)$ & $1.63(3)$ & $1.60(2)$ & $0.081(2)$ & $0.091(4)$ & $0.103(1)$ \\
\hline & $\mathrm{W}=\mathrm{O}^{e}$ & $1.704(9)$ & $1.687(14)$ & $1.680(12)$ & $0.325(1)$ & $0.333(1)$ & $0.320(1)$ \\
\hline $\mathrm{Cap}^{c}$ & $\mathrm{~W}=\mathrm{O}$ & $1.728(9)$ & $1.729(13)$ & $1.703(11)$ & $0.374(1)$ & $0.374(1)$ & $0.369(1)$ \\
\hline Belt $^{d}$ & $\mathrm{~W}=\mathrm{O}$ & $1.723(9)$ & $1.717(13)$ & $1.705(11)$ & $0.330(7)$ & $0.329(8)$ & $0.326(9)$ \\
\hline
\end{tabular}

${ }^{a}$ Doming distance (i. e. out-of-plane displacement) corresponds to the distance from the plane defined by the four equatorial oxygen atoms (two each from the two coordinating POM fragments) to the metal cation. ${ }^{b}$ Metal coordinated between the two $\left[\mathrm{PW}_{9} \mathrm{O}_{34}\right]^{9-}$ fragments; ${ }^{c}$ Three edge-shared octahedra (on each POM fragment), which are not coordinated to the sandwiched metal(s); ${ }^{d}$ Six octahedra (on each POM fragment) coordinated to the sandwiched metal(s) and corner-shared with the cap; ${ }^{e}$ The metal-oxo group is directed inwards towards the center of the complex, as opposed to the usual outward direction of the other metal-oxo groups. 
Figure S3. Ultra-low-temperature (5 K) electronic absorption spectrum of 2 collected as a 1:3 water:glycerol optical glass. Absorption maxima are found at $19,750 \mathrm{~cm}^{-1}$ (sh) and $22,700 \mathrm{~cm}^{-1}$.

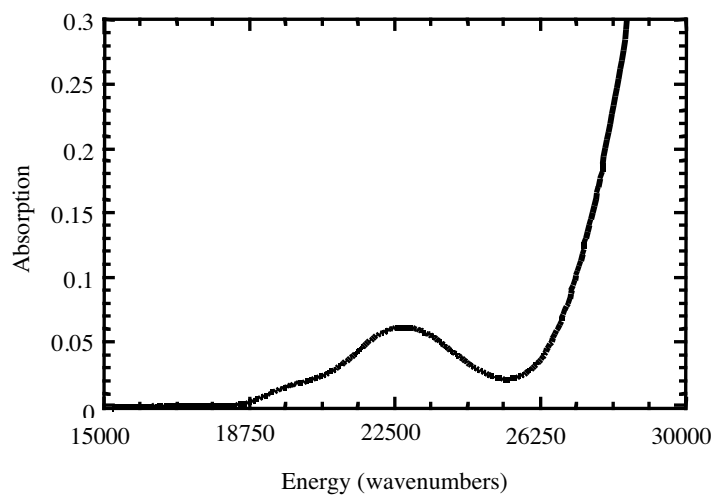


Figure S4. ${ }^{17} \mathrm{O}$ NMR spectra of (A) 2 and (B) $\mathbf{P}_{\mathbf{2}} \mathbf{W}_{\mathbf{2 0}}$.

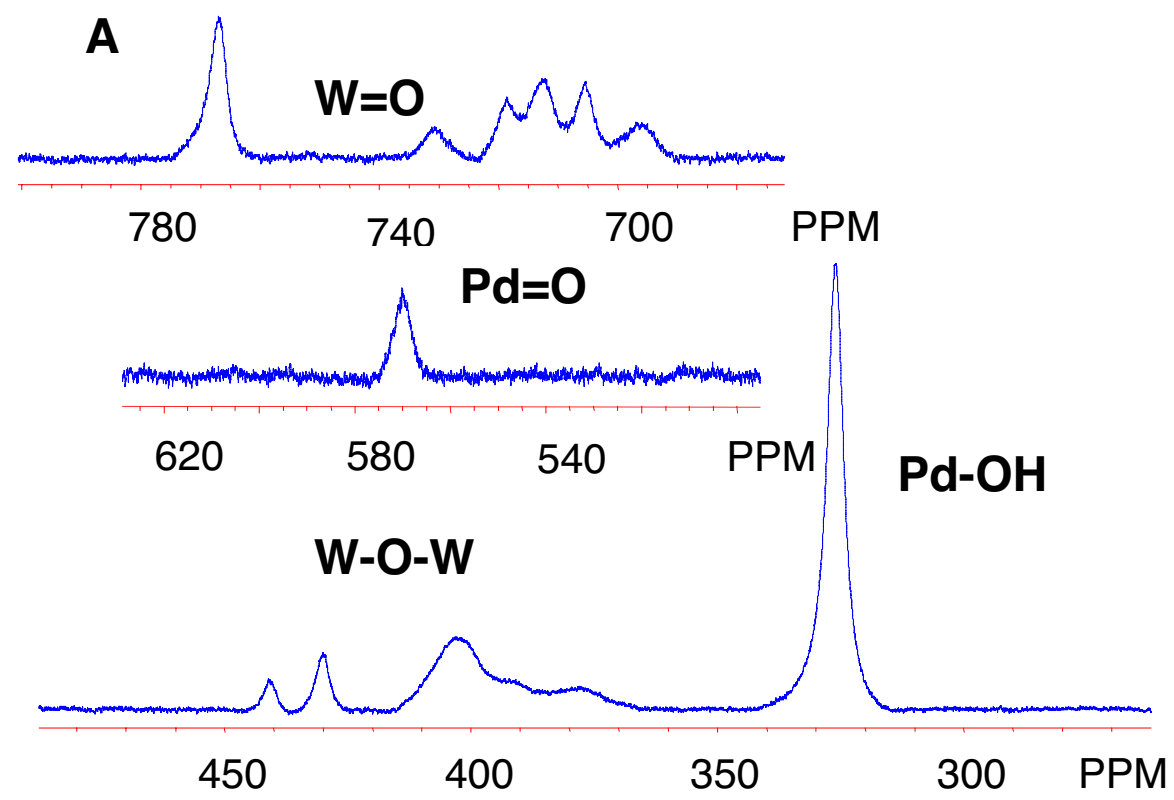

B

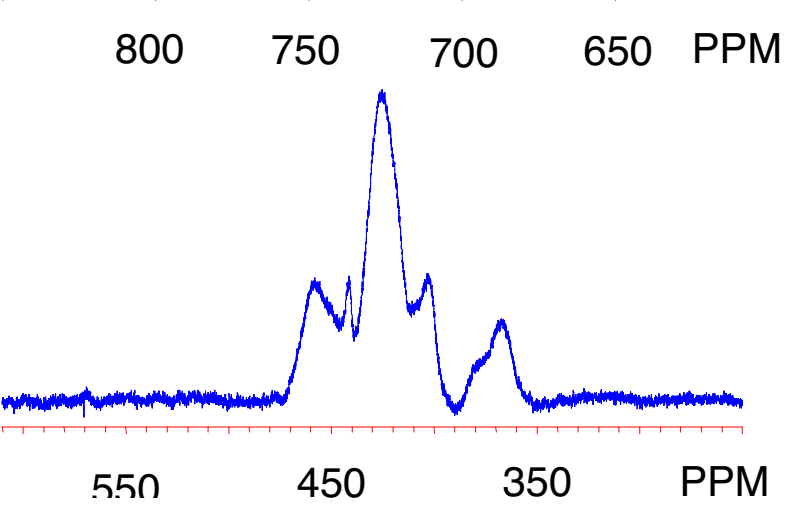


Table S3. Curve fitting results for the Pd $K$-edge EXAFS of 2.

\begin{tabular}{|c|c|c|c|c|c|c|}
\hline Fit \# & $\begin{array}{l}\text { Coordination model } \\
\text { for the first shell }\end{array}$ & $N$ & Scatterer & $R, \AA$ & $\sigma^{2}, \AA^{2}$ & Fit error \\
\hline \multirow[t]{5}{*}{1} & $5 \mathrm{O}$ & 5 & $\mathrm{O}$ & 1.97 & 0.0043 & 0.217 \\
\hline & & 4 & $\mathrm{~W}$ & 3.60 & 0.0021 & \\
\hline & & 4 & $\mathrm{O}-\mathrm{W}$ & 3.73 & 0.0021 & \\
\hline & & 2 & $\mathrm{~K}-\mathrm{O}$ & 3.98 & 0.0023 & \\
\hline & & 8 & $\mathrm{O}-\mathrm{O}$ & 4.67 & 0.0043 & \\
\hline \multirow[t]{5}{*}{2} & 60 & 6 & $\mathrm{O}$ & 1.97 & 0.0055 & 0.263 \\
\hline & & 4 & W & 3.60 & 0.0021 & \\
\hline & & 4 & $\mathrm{O}-\mathrm{W}$ & 3.73 & 0.0020 & \\
\hline & & 2 & $\mathrm{~K}-\mathrm{O}$ & 3.98 & 0.0023 & \\
\hline & & 8 & $\mathrm{O}-\mathrm{O}$ & 4.67 & 0.0044 & \\
\hline \multirow{6}{*}{3} & $1 \mathrm{O}$ & 1 & $\mathrm{O}$ & 1.71 & 0.0154 & 0.181 \\
\hline & $4 \mathrm{O}$ & 4 & $\mathrm{O}$ & 1.96 & 0.0028 & \\
\hline & & 4 & W & 3.60 & 0.0027 & \\
\hline & & 4 & $\mathrm{O}-\mathrm{W}$ & 3.73 & 0.0023 & \\
\hline & & 2 & $\mathrm{~K}-\mathrm{O}$ & 3.96 & 0.0026 & \\
\hline & & 8 & $\mathrm{O}-\mathrm{O}$ & 4.66 & 0.0045 & \\
\hline \multirow[t]{6}{*}{4} & 10 & 1 & $\mathrm{O}$ & 1.68 & 0.0067 & 0.151 \\
\hline & $5 \mathrm{O}$ & 5 & $\mathrm{O}$ & 1.96 & 0.0043 & \\
\hline & & 4 & W & 3.60 & 0.0023 & \\
\hline & & 4 & $\mathrm{O}-\mathrm{W}$ & 3.73 & 0.0023 & \\
\hline & & 2 & $\mathrm{~K}-\mathrm{O}$ & 3.97 & 0.0026 & \\
\hline & & 8 & $\mathrm{O}-\mathrm{O}$ & 4.67 & 0.0046 & \\
\hline \multirow[t]{7}{*}{5} & 10 & 1 & $\mathrm{O}$ & 1.71 & 0.0146 & 0.160 \\
\hline & $4 \mathrm{O}$ & 4 & $\mathrm{O}$ & 1.96 & 0.0027 & \\
\hline & $1 \mathrm{O}$ & 1 & $\mathrm{O}$ & 2.41 & 0.0047 & \\
\hline & & 4 & W & 3.59 & 0.0024 & \\
\hline & & 4 & O-W & 3.73 & 0.0023 & \\
\hline & & 2 & K-O & 3.95 & 0.0027 & \\
\hline & & 8 & $\mathrm{O}-\mathrm{O}$ & 4.62 & 0.0044 & \\
\hline
\end{tabular}

$N$ is the coordination number, $R$ is the mean distance, $\sigma^{2}$ is the bond length variance. The fit error is defined as $\left[\Sigma\left(\chi_{\exp }-\chi_{\text {calc }}\right)^{2} k^{6} / \Sigma \chi_{\exp }{ }^{2} k^{6}\right]^{1 / 2}$, where $\chi$ is the EXAFS data point. The accuracies estimated for bond lengths are approximately $\pm 0.03 \AA$; resolution is $0.14 \AA$. 
Figure S5. EXAFS and Fourier transforms for fits 1-4.
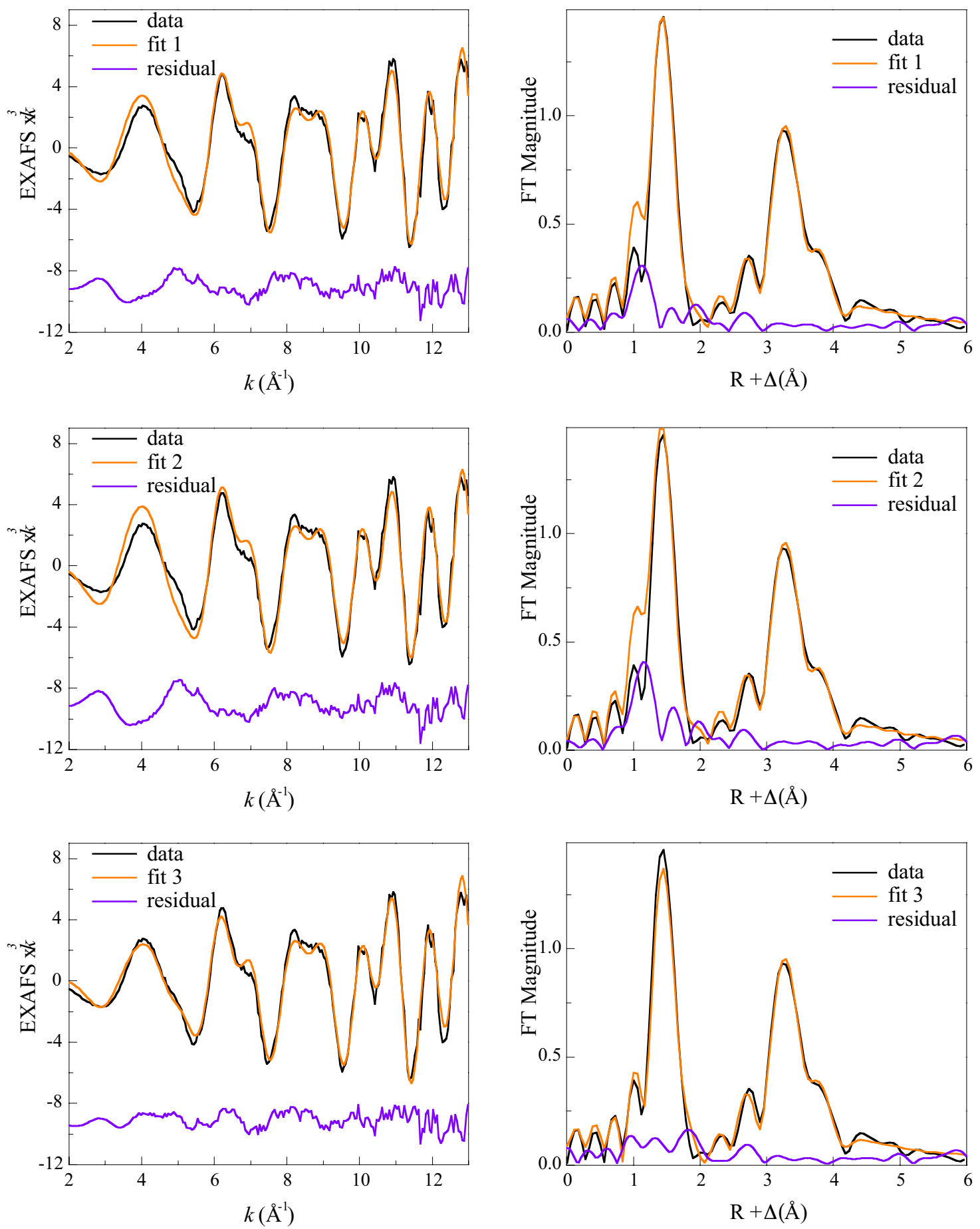

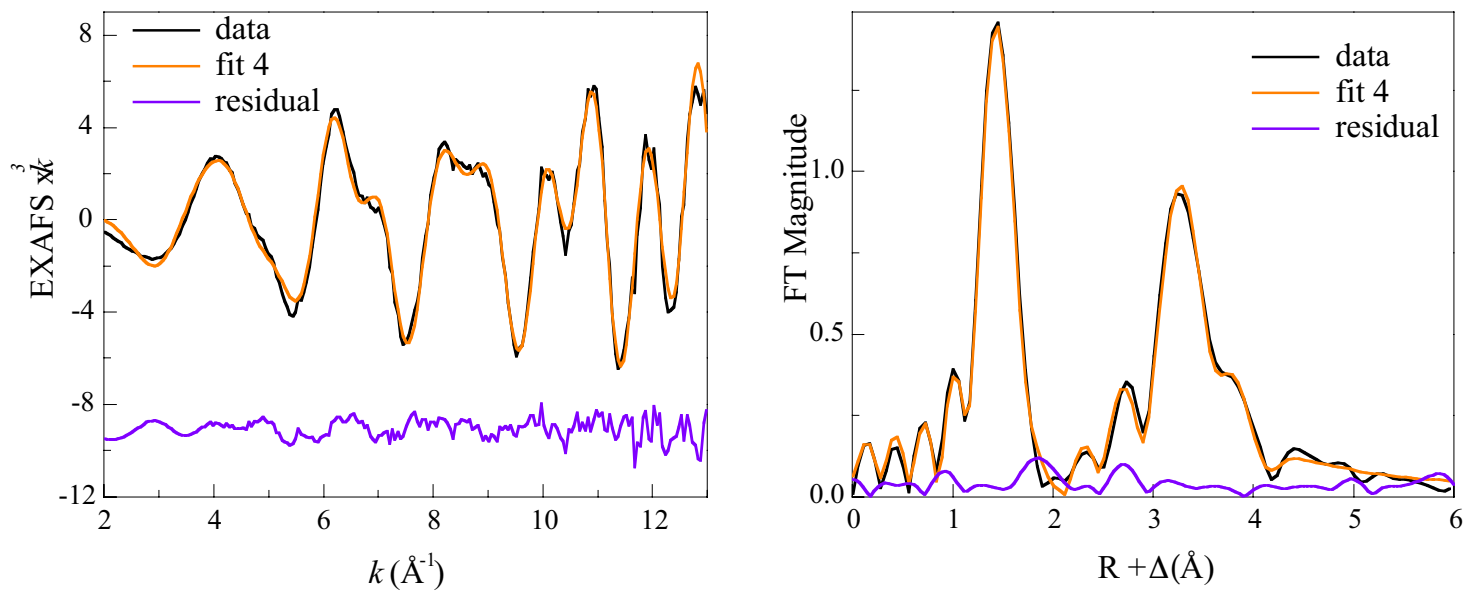
Figure S6. Individual EXAFS components in fit 4.

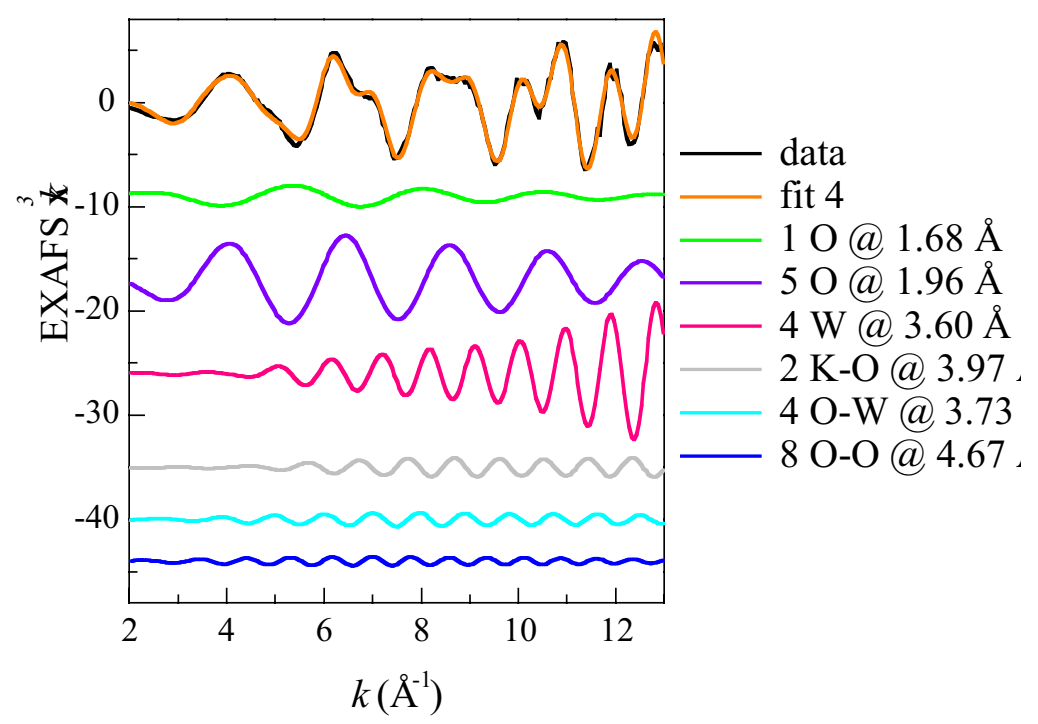


Figure S7. Cyclic voltammetric characterization of a thick film of $\mathbf{2}$ in its preparation medium ( $0.2 \mathrm{mM}$ of 2 in a $0.4 \mathrm{M}$ acetate buffer, $\mathrm{pH} 4.5)$. The working electrode is glassy carbon, the reference electrode is SCE, and the scan rate is $2 \mathrm{mV} \mathrm{s}^{-1}$.

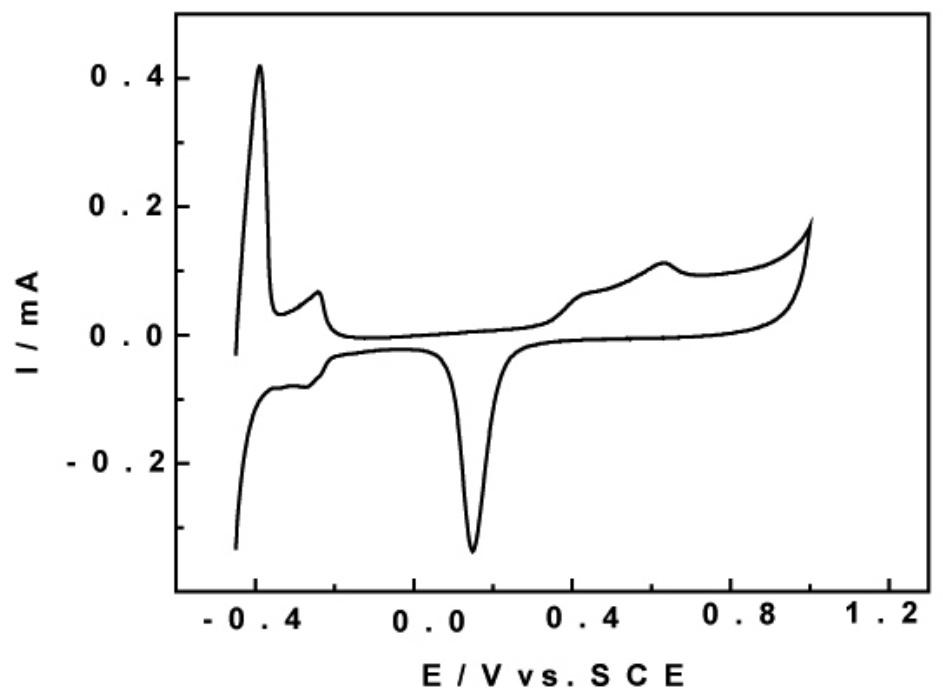

